\title{
The Meanings of Timbuktu
}

Shamil Jeppie and Souleymane Bachir Diagnes, eds.

Pretoria: Human Science Research Council in association with

Dakar: CODESRIA, 2008. 376 pages.

Former South African president Thabo Mbeki took a proactive stand in recognizing the significance and importance of Timbuktu's rich African Muslim scholarly legacy after he visited the city during his official visit to Mali in November 2001. As a consequence of this trip, he initiated the South Africa-Mali Timbuktu project, which was subsequently declared a special "South African President" project. Apart from deepening the relations between these two nation-states, one extremely important outcome was the South African Department of Arts and Culture-supported conference held in Cape Town in August 2005. The book under review, which consists of the papers presented, was produced by Shamil Jeppie (advisor to South Africa's inter-ministerial committee, which is also responsible for this special project, and a historian based at the University of Cape Town) and Souleymane Bachir Diagne (professor of philosophy, Northwestern University [Illinois]).

This invaluable text makes African scholarship proud and has injected new life into Timbuktu and its manuscript tradition. The mere fact that it was aesthetically produced and accompanied by appropriate eye-catching illustrations is evidence that the editors took pride in compiling and editing material that would, upon first glance, attract the public eye. That said, the book 
itself is divided into five distinct sections consisting of twenty-four chapters, including the editors' two introductory chapters.

The book opens with an outline, a preface, an acknowledgment, and a useful historical timeline. Jeppie, the lead editor, reflects upon "Re/discovering Timbuktu," and Diagne shares his ideas on "Toward an Intellectual History of West Africa: The Meaning of Timbuktu." While Jeppie sets the scene by discussing, among other matters, the South African government's initiatives to get involved with conserving and preserving Timbuktu's manuscripts, Diagne critically assesses the West African intellection tradition and sheds light on the meanings denoted by Timbuktu. Apart from drawing lessons, he declares that "(w)hat Timbuktu and other places where Islamic scholarship was developed teach us is to have a sense of history that opposes this identification of Africa with orality, a generalization which is just not accurate" (p. 19).

Part 1, which introduces us to the region of Timbuktu, features essays by scholars who have researched West Africa in general and Timbuktu in particular. Roderick J. McIntosh provides us with an insight into its archaeological and geographical setting in his "Before Timbuktu: Cities of the Elder World"; Jonathan M. Bloom argues that the history of "Paper in Soudanic Africa" differs from that observed in the other parts of the Muslim heartland; Sheila Blair highlights the characteristics of the West African Arabic script, Qur'anic manuscripts, and the development of "Arabic calligraphy in West Africa"; and Timothy Cleaveland corrects some of the mistaken views about West Africa's medieval education institutions in his "Timbuktu and Walata: Lineages and Higher Education."

Part 2, "Arabic Literature as a Source of African History," contains six contributions on different aspects of the Arabic literary tradition. In his "Intellectual Innovation and Reinvention of the Sahel: The Seventeenth-Century Timbuktu Chronicles," Paulo F. de Moraes Farias reveals the significant roles of Ibn as-Sa'di's Tarikh us-Sudan (Chronicle of Sudan [completed 1653]) and Ibn al-Mukhtar's Tarikh al-Fattash (Chronicle of the Researcher [completed 1664]) played in recording the early historical developments in the Sahel region. Moulaye Hassane surveys "Ajami in Africa: The Use of Arabic Script in the Transcription of African Languages" before referring to specific subjects, such as grammar and jurisprudence, that were written in Hausa and Fululde employing the Arabic script.

Hamid Boboyyi's "Ajami Literature and the Study of the Sokoto Caliphate" mentions some of the problems related to tracing the history of ajami Islamic verse in Bilad us-Sudan. Murray Last narrates the fascinating story of "The Book in the Sokoto Caliphate" with specific focus on the man- 
uscript. He periodized the data of the manuscripts he perused during the early 1960s and the 1970s as being between 1400 and 1900, and thereafter discusses book merchandising and production in the nineteenth century. Beverly B. Mack undertakes a comparative study about a neglected subject: "Muslim Women Scholars in the Nineteenth and Twentieth Centuries: Morocco to Nigeria," and Aslam Farouk-Alli and Shaheed Mathee demonstrate, in their coauthored "The Tombouctou Manuscript Project: Social History Approaches," how selected legal Timbuktu texts could be significant sources for historical inquiry.

The four chapters comprising part 3 address the important intellectual role of the respected Kunti "Scholars of Timbuktu." Yahya Ould el-Bara's "The Life of Shaykh Sidi al-Mukhtar al-Kunti (d. 1811)" begins by telling us about Sufism's institutionalization and then describes the development of the Qadriyya Sufi order, to which the shaykh belonged. Mahamane Mahamoudou complements that chapter by focusing on "The Works of Shaykh Sidi al-Mukhtar al-Kunti," many of which have been located in the refurbished and transformed Ahmad Baba Institute of Higher Islamic Studies and Research. Abdel Wedoud Ould Cheikh recounts the tale of "A Man of Letters in Timbuktu: Al-Shaykh Sîdi Muhammad al-Kunti (d. 1826)," who played a critical role in both the religious arena and the political sector. Mohamed Diagayeté unpacks the life of "Abul Khayr al-Arawani: A Great Scholar and Pious Saint" of the twentieth century by identifying his lineage, evaluating his activities, and assessing some of his works.

In part 4, the contributors focus on "The Timbuktu Libraries." Abdelkader Mamma Haidara describes "The State of Manuscripts in Mali and Efforts to Preserve Them," and Ismaël Diadié Haidara and Haoua Taore discuss the formation of "The Private Libraries of Timbuktu," which is a fairly new phenomenon in Mali. Mukhtar bin Yahya al-Wangari assesses the contribution of "Shaykh Baghayogho al-Wangari (d. 1594) and the Wangari Library in Timbuktu." Sidi Mohammed Ould Youbba, who records the emergence and development of "The Ahmed Baba Institute of Higher Islamic Studies and Research," informs us about its objectives and tells us about the efforts to preserve the manuscripts housed there. John Hunwick, the wellknown scholar on West A frican Islam, evaluates "The Arabic Literature of the Africa Project," which started out as a project at the University of Ibadan in 1964. He then updates us on the painstaking Arabic Literature of Africa series that has been produced with the assistance of a team of scholars and researchers from - and beyond - Sudanic Africa (i.e., Bilad al-Sudan or the Sahelian region). Apart from sharing with us about the manuscript collections in West Africa, Hunwick also provides an overview of West African 
scholarly traditions. Charles Stewart, another scholar of note, portrays his personal involvement in "The West African Arabic Manuscript Database that began almost two decades ago. He calls the database the "Arabic Manuscript Management System" (AMMS) and briefly discusses, inter alia, the Timbuktu entries in it.

The final part of this beautifully designed and edited text takes us to "Beyond Timbuktu." Here, however, we only have two entries. The first, "Arabic Literature in the Eastern Half of Africa," is Sean O'Fahey's survey of the situation of Arabic literature in northeastern and eastern Africa and reviews one of the volumes of the Arabic Literature of Africa series mentioned by Hunwick. Anne K. Bang assesses "Textual Sources on an Islamic African Past: Arabic Material in Zanzibar's National Archive." She outlines the historical collection at Zanzibar's National Archive and evaluates some of the historical topics and themes that have been researched. In addition, she gives ideas about the state of preservation at the Archives and suggests areas that may be pursued in the future. Since this section looked beyond Timbuktu, the question may be asked why the editors did not include a chapter on the ajami texts in South Africa's Cape Town or, for that matter, some of the extant writings that have been located in northern Mozambique, to demonstrate the existence of other ajami texts in southern Africa?

In conclusion, despite the beautifully designed and presented edited work, there were some minor oversights, such as the inconsistent spelling of the names of towns. Such errors, however, in no way detract me from recommending this skillfully and expertly edited work. In my view this work, which is accompanied by a user-friendly index, will remain a valuable source text and one that African studies programs should incorporate in their existing list of readings on West African Islam.

Muhammed Haron Senior Lecturer, Department of Theology and Religious Studies University of Botswana, Gaborone, Botswana 